Richard B. SHERIDAN

\title{
CHANGING SUGAR TECHNOLOGY AND THE LABOUR NEXUS IN THE BRITISH CARIBBEAN, 1750-1900, WITH SPECIAL REFERENCE TO BARBADOS AND JAMAICA
}

Technology can be defined as the organization of knowledge for the achievement of practical purposes. It consists of knowledge, skills, methods, tools, and machines that enable people to shape materials and produce objects for practical ends. In this paper I will examine the pattern and direction of technological change in the cane sugar industry of the British West Indies and analyze the impact of this change on the employment, productivity, and welfare of workers engaged in the production of sugar. I will use the term "technology" in a comprehensive sense to include techniques and such non-material aspects as management, organization of work, and other elements of social organization. I plan to compare the sugar islands of Barbados and Jamaica from circa 1750 to 1900 in terms of innovations which changed the processing structure, changes in the agricultural sphere, and connections between technological developments and changing labour relations. I shall be concerned with the geographic environment and the technology which made that environment useful; with the availability of capital, access to skilled and unskilled labour, presence or absence of members of the planter class, metropolitan influences, changing sugar prices, duties, and profitability. Barbados, with its high density labour force and compact and relatively uniform physical characteristics, will be contrasted with Jamaica, its low density labour force and extended and diverse physical characteristics (Barbour 1980: 30, 35-36).

I.Z. Bhatty maintains that since agriculture is basically a biological process, it is important to distinguish between mechanical and biological technology. "The former", he writes, "makes non-human power available 
or provides the means through which non-human power could be productively utilized, in place of human or animal power." Prior to the application of steam power to the sugar industry, non-human mechanical power took the form chiefly of horse-mills, windmills, water-mills, and tide-mills to crush the canes. Biological technology, on the other hand, improves animal and plant production by increasing the effective supply of nutrients. Plant productions can be increased by either increasing the effective supply of nutrients available or by making it possible for the plant to utilize larger amounts of available nutrients, or, both. Fertilizers and assured water supply are means of the first kind, improved seeds or plant material of the second (Bhatty 1978: 3-11).

The typical sugar plantation of the British West Indies has been described as a factory in the field. The agricultural processes of land preparation, cane-planting, weeding, and cutting were combined with grinding the canes, boiling the cane juice, curing and refining the sugar, and distilling the molasses into rum. This combination of biological and mechanical technology was made necessary by the inherent perishability of the crop. Owing to its rapid fermentation, the newly-cut sugarcanes had to be milled within about twenty-four hours if sugar of marketable quality was to be produced. Milling time was thus limited, while on the other hand transport from the field to the mill was slow and cumbersome. Richard Pares (1960:245) has calculated that a muscovado sugar factory could not profitably serve an estate or plantation of more than 300 to 350 slaves, tending an acreage of sugarcane which probably would not exceed 300 in all. Managing a sugar plantation, which usually combined agriculture with a processing plant or "sugar-works", was a complex affair. It required foresight, calculation, and coordination. In his Essay Upon Plantership, Samuel Martin of Antigua said that a sugar plantation "ought to be considered as a well constructed machine, compounded of various wheels, turning different ways, and yet contributing to the great end proposed; but if any one part runs too fast or too slow, in proportion to the rest, the main purpose is defeated" (Martin 1802: 57-8; see also Barrett 1965: 147-70; Mintz 1986: 19-73; Smith 1975: 57-77; Sheridan 1974: 102-23).

To a greater degree than the other British sugar islands, Barbados was the island where the sugar plantations came to be conducted as if they were "well constructed machines". David Watts has shown how the sugar revolution of the mid-seventeenth century had the effect of removing practically all of the standing forest of Barbados by 1665 , that the planting of canes in trenches or furrows led to destructive soil erosion which heavy applications of animal manure did little to correct, and that the development 
of cane hole agriculture, while it imposed inordinately severe labour requirements on the field slave, led to a sustainable system of sugar cane farming after the early years of the eighteenth century. Under the "driving system", cane holes were dug by gangs of slaves who were drawn out in a line, like troops in a parade. Goaded on by black drivers who wielded cart whips the slaves raised and chopped down with their hoes in unison, as they moved forward from one row of cane holes to the next. This was the most conspicuous and enervating part of the new industrial labour discipline which, as Robert W. Fogel asserts, was the sugar planters' "greatest technological achievement, the foundation of their economic success, and the ugliest aspect of their system". Other innovations resulting from soil deterioration and soil loss were extending the growth period of cane prior to harvest from 15 to 18 months, improved and extended manuring practices, and specialized dung farms (Watts 1987: 391-405; Sheridan 1985: 148-54; Fogel forthcoming ${ }^{\prime}$ ).

The statistics shown in Table I indicate that while the slave population of Barbados increased by about 33 percent from circa 1700 to 1775 , the output of sugar declined by 27 percent, and the value of exports to Great Britain increased by 44 percent.

TABLE 1: Barbados AND Jamaica COMPARED, CIRCA 1700 TO 1775:

Slave Ppopulation, Sugar Output, Value of Exports to Great Britain

\begin{tabular}{llllcc}
\hline & Year & $\begin{array}{l}\text { Slave } \\
\text { Population }\end{array}$ & $\begin{array}{l}\text { Sugar Output } \\
\text { (tons) }\end{array}$ & $\begin{array}{l}\text { Value of Exports } \\
\text { to Great Britain } \\
\text { f Sterling }\end{array}$ \\
\hline Barbados & 1687 & - & - & & 196,532 \\
& 1710 & 52,337 & 7,690 & - \\
Jamaica & 1773 & 68,548 & 5,634 & & 282,652 \\
& 1697 & - & - & & 70,000 \\
& 1703 & 45,000 & 4,321 & - & - \\
& 1778 & 205,261 & 36,519 & $(1770)$ & $1,384,420$ \\
\hline
\end{tabular}

Source: Campbell 1774: II, 669; Williams 1944: 226; Pares 1960: 84.

Part of the explantion of why there was a decline in sugar output in a period when the value of exports from Barbados to Great Britain increased is that a greater proportion of the sugar consisted of clayed, or semirefined, which commended higher prices than muscovado sugar in British markets. Another part of the discrepancy is that raw cotton production and exports increased relative to that of muscovado and clayed sugar. Included among the factors that contributed to the decline in the sugar 
output of Barbados were wartime losses, drought and hurricanes, epidemic disease, slave mortality and morbidity, emigration of planters and their slaves to other sugar colonies, absentee proprietorship, loss of soil fertility, and decline in crop yields. Handler and Lange (1973: 34-41) have estimated "that during most of the plantation slave period there were, on average, close to 400 medium and large plantations which contained between 100 to 200 slaves. In addition there was a large number of small-holdings which contained eight or ten acres, or more, with slaves in proportion". By using such criteria as land ownership, public offices held, and rank in the military, Watson (1975: 64-78) finds that "approximately 120 families dominated island history from the early period of colonization and even into present times, many of these families still ranking among the island's elite, now known as 'high whites' ".

By the middle decades of the eighteenth century the sugar planters of Barbados had arrived at a capital-intensive, power-intensive, and labourintensive system of sugarcane agriculture that was conducted on a sustainedyield basis, albeit with a net annual decrease in the slave and livestock populations. It was the judgment of Sir Robert Schomburgk, the midnineteenth century historian of Barbados, that "a rational management replaced by artificial means the former fertility" of the island. Indeed he affirmed that the island had "not undergone deterioration since Governor Sir Jonathan Atkins's time (1674-80), when it was considered to have reached its meridian prosperity, - a period which has been styled the golden age of Barbados" (Schomburgk 1848: 140-141).

By the standards of the seventeenth and eighteenth centuries, Jamaica was a large sugar island. It was nearly twenty-seven times as large as Barbados, measured in square miles. It is misleading, however, to compare these two islands solely on the basis of physical size. Barbados is only 21 miles long en 14 miles wide. It has an area of 166 square miles $(106,000$ acres), and it has been densely populated for some three centuries. It was very flat, with rising terraces which culminate in Mount Hillaby, the highest point, 1,115 feet above sea level. With the exception of the Scotland District in the northeast, Barbados is of coral limestone formation, which has weathered to generally fertile, well-drained and loamy soils on terraces. Moreover, the rainfall is generally adequate and distributed seasonally to grow the sugarcanes, and the trade winds are persistent and generally of sufficient strength to power the windmills (Watts 1966: 4-14; Handler \& Lange 1978: 9-15).

While Barbados has been a sugar island of intensive monoculture for nearly three centuries prior to recent decades, Jamaica developed as an 
island of extensive sugar monoculture only during the century prior to slave emancipation in 1838 . We shall see that it subsequently developed a mixed economy of plantation and peasant agriculture in which sugar production and exports declined relative to those of other staples. Jamaica, which lies approximately 1,200 miles to the west of Barbados, is about 145 miles long with a maximum width of about 50 miles and an area of 4,411 square miles. More than half of the island consists of rugged slopeland lying 1,000 feet or more above sea level, with a range of mountains running east and west which reach a height of 7,500 feet in the Blue Mountains in the eastern part of the island. The moisture-laden trade winds dump 200 or more inches of rain on the higher slopes of the Blue Mountains, while the southern and western lowlands, lying in the rain shadow, are often too dry for agriculture without irrigation. There are three parts of Jamaica that are suited to the production of sugar: coastal areas; land along the lower basins and deltas of large rivers; and fertile inland valleys (Hall 1959: 13-14; McPherson 1963: 31-51).

The beginning of the sugar industry of Jamaica is generally credited to Governor Sir Thomas Modyford, the former planter-governor of Barbados, who arrived in Jamaica in 1664 with some 700 planters and their slaves. This was the beginning of a long association which was noteworthy for the transfer from Barbados to Jamaica of planters, slaves, capital, and mechanical and biological technology.The sugar industry grew rapidly for several decades after Modyford's arrival, but was severely handicapped during the greater part of the period from 1689 to 1713 by wars with Spain and France. There was another growth spurt after the Treaty of Utrecht in 1713, but it was halted in the decade of the 1730s by severe drought, depressed sugar prices in England, and internecine warfare against the Maroons, communities of ex-slaves that found refuge in the rugged interior of Jamaica and lived by hunting wild game, growing food crops, and raiding frontier plantations and settlements. After the treaty with the Maroons in 1739, however, "settlements began to be formed in those parts of the country where none chose to venture before". From approximately 70 sugar plantations in Jamaica in 1675 , the number increased to 419 in 1739, 648 in 1776, and 775 in 1774 (Sheridan 1974: 92-5, 208-23, 420; Long 1774: I, 427-9; MacPherson 1805: III, 505).

Table 1 above supplies some key indicators of the growth of the Jamaican sugar industry from circa 1700 to 1775 . The slave population increased five-and-a-half times; sugar output, eight-and-one-half times. In 1770 sugar and rum made up 87.7 percent of the value of all exports from Jamaica to Great Britain, Ireland, and North America which amounted to $£ 1,538,730$. Other exports in 1770 consisted of cotton, coffee, ginger, pimen- 
to, sarsaparilla, mahogany, and hides. A similar calculation of Barbados's exports to Great Britain, Ireland, and North America shows that sugar and rum accounted for 62.5 percent of all exports which amounted to $£ 432,013$ in 1770 . Other exports from Barbados in 1770 consisted of cotton, aloes, ginger, and hides (Campbell 1794: II, 661-6, 669).

An important biological innovation contributed to the expansion of Jamaica's sugar economy. Bryan Edwards, the planter-historian, wrote that "Guinea-grass may be considered as next to the sugar-cane, in point of importance, as most of the grazing and breeding farms or pens throughout the island, were originally created, and are still supported, chiefly by means of this invaluable herbage." Guinea grass was introduced into Jamaica from West Africa by George Ellis, Chief Justice, in the period 1736-1740 (Edwards 1793: I, 185-6).

The Jamaica planter elite profited from a system of sugar production which spread dear capital and labour thinly over the rich resource base. Large land grants and low taxes enabled the planters to hold reserve tracts at a low cost for purposes of speculation or future expansion of sugar production. According to Edward Long, the Jamaica planter-historian, almost all of the overseers on the island

consider the number of acres they can annually overspread with [cane] plants, as the surest test of their ability, without reflecting, that extraordinary pains, bestowed on half the quantity, would yield an equal crop. Others wear out their lands by incessant cultivation, and a neglect of recruiting it with seasonable supplies of mould, or other dressing; and, after throwing it up, pass on to a new piece, which is destined to be worked to the bone in the same manner; and very few of them understand the method of preparing suitable compost for their land.

Unlike their counterparts in Barbados, who were early forced to apply fertilizer to their cane-lands, the planter of Jamaica took advantage of large areas of virgin land that cost little more than the clearing to grow canes until the fertility declined, and then shifted their labour force and other resources to open new lands in what may be described as a system of extensive sugar monoculture that was combined with a pastoral economy of some moment (Long 1774: I, 439-41; Sheridan 1974: 219-21).

Some efforts were made to reform the sugar plantation economy during the third quarter of the eighteenth century. The genesis of this movement is associated with growing absenteeism, for it was customary for planters to sit down on the eve of their departure for Europe and draw up written instructions for their managers and attorneys. Some of these instructions were later revised and expanided in the light of trial and error experiments and published as manuals that were sold to members of the plantocracy. 
Samuel Martin, the leading planter of Antigua, was a case in point. For some years he and his family alternated between Antigua and England before he settled down in 1750 to improve the performance of his plantation and slaves. His Essay Upon Plantership, which was first written for the instruction of a young planter at an unknown date, went through seven editions and at least two reprints down to 1802. As I have told Martin's story as an innovating planter elsewhere, it is sufficient to say that he was a close student of Jethro Tull and other agricultural improvers in England and experimented with the ideas of writers on the "New Husbandry" on his Greencastle plantation. His efforts to improve his own plantations met with considerable success and his influence in the later years of his life (he died in 1777) was widespread (Sheridan 1960).

The period from 1775 to 1806 in the British West Indies was one of recurrent warfare, natural disasters, cost-price fluctuations, slave insurrections, pressure to reform and abolish the transatlantic slave trade and plantation slavery, and biological and mechanical innovations. Partly to counteract the propaganda of the abolitionists, partly to forestall slave revolts, and partly to restore their plantation profits after the destruction of wars and hurricanes, the more enlightened British planters looked for ways to reduce costs and raise revenues by means of managerial and technological innovation. They read the planter manuals written by Samuel Martin and other authorities and applied these ideas to their own estates. They formed agricultural societies which disseminated new ideas and the results of local experiments. As members of colonial legislatures, they received and acted upon petitions from local inventors seeking patents of monopoly, and they offered prizes to inventors of successful devices.

The Journals of the House of Assembly of Jamaica contain much information concerning improvements in the mechanical technology of the sugar industry. During the last quarter of the eighteenth century, when inventors and innovators were perhaps more active than in earlier or later periods, the Assembly received applications for patents of monopoly from 28 individuals, of whom 21 were designated by occupation, profession, or class. Professional men and skilled tradesmen consisted of two doctors, two millwrights, and one each of engineer, projector and engineer, carpenter, cabinet maker, mason, chemist, and mechanic. Additionally, there were five esquires, three planters, and two gentlemen. In a society of considerable occupational and social mobility, it was perhaps not unusual to find former artisans among the colonial gentry. ${ }^{2}$ 
Practically all phases of the technology concerned with crushing or milling, clarifying, curing, and distilling were allegedly improved by the inventors and innovators who sought patents of monopoly. For example, the inventions were variously described as a "new invented mill for grinding of sugar-canes", "an improved cattle mill for sugar estates", "an improvement on wheels for turning water-mills", "a hydraulic machine which raises water in any quantity", "a new method of hanging coppers for clarifying cane-liquor", "a method of greatly improving the manufacture of muscovado sugar and distillation of rum." In addition to sugar technology, several petitions described improved methods and machines for curing coffee beans and ginning cotton.

The spread of the Industrial Revolution to the West Indies is evident from the number of petitioners who claimed to have successfully applied steam power to cane-crushing mills. Noel Deerr says "the first attempt to use steam power in the manufacturing process was made in Jamaica in 1768 at Greenwich plantation in the parish of St. Andrew". After the attempts to install old style Newcomen atmospheric or fire engines failed, the field was opened to improved engines manufactured by the British firms of Messrs. Boulton and Watt and Messrs. Fawcett, Preston and Company. These two firms supplied Jamaica with 65 cane mill engines from 1802 to 1852 . Barbados, on the other hand, did not receive the first steam engine to power cane crushing mills until 1846; at that time the island had 506 windmills (Deerr 1949-50: II, 552-3; Deerr \& Brooks 19401; Watts 1987: 405-25).

Contemporary authorities found little to praise and much to condemn in the conduct of field operations by Jamaican planters. Although Edward Long was encouraged by a "spirit of experiment" which had of late appeared, he nevertheless found "vast room for improvement". One difficulty was by reason of the great variety of soils and diversity of climate, one system of management that was successful in one part of the island was "utterly improper, and extremely detrimental in another". In explaining why no trial had been made of the "soft unctuous marle" which was plentiful in Jamaica, Edwards believed it was because the planters in general had no leisure for experiments, and that it was "difficult to make agents and servants (who have every thing to risk, and nothing to gain) walk out of the sure and beaten track of daily practice. Every man's experience confirms this observation." (Long 1774: I, 435-45; Beckford 1790: II, 1937; Edwards 1793: II, 212-5).

Hoe culture on the sugar plantations appears to have been incongruous in an age when progressive farmers in England were following the practices outlined in Jethro Tull's The Horse-Hoe Husbandry. Samuel Martin wrote 
that infinite hand labour could be saved by use of the Kentish hoe-plough in weeding canes, but he found by experience that stiff or heavy clay soils required more strength of cattle and horses to draw ploughs than the small pastures of the Eastern Caribbean islands could sustain. Long argued that "because no work on a plantation is so severe and so detrimental to them [field slaves] as that of holing, or turning up ground in trenches with their hoes, planters should adopt the plough not only to save the labour of a great many slaves, but also to cultivate more ground every year and produce sugar of superior quality". Indeed, Long asserted that in Jamaica "one plough turned up so much ground in one day, and in a much better manner, than 100 Negroes could perform with their hoes in the same time", the plough land yielding 3 hogsheads per acre, the same hoed 2 hogsheads. Edwards said that the plough had been introduced into Jamaica of late years and in some cases to great advantage, however, it was not practicable in every soil or situation. He maintained that the only advantageous system of ploughing in the West Indies was to confine it to the simple operation of holing, but that this operation could be performed with much greater facility and dispatch if the stiff and dry soils were first turned over with animal-drawn ploughs. John Davy, M.D., who lived in Barbados in the $1840 \mathrm{~s}^{4}$, observed that prior to the abolition of the slave trade in 1808, the hoe was almost the only tool employed in cane or other cultivation. After abolition, however, planters apprehended a deficiency of labourers and introduced the plough and harrow. In Barbados, the success of implemental husbandry was marked and encouraging until the arrival of drought and short crops in the decade of the 1820 s, when "the plough fell into disuse, and the exclusive hoe was resumed" (Martin 1802: 60-2; Long 1774: I, 448-51; Edwards 1793: II, 204-7; Davy 1854: 113).

Modern writers contend that the labour-intensive system of hoe culture, while it was unnecessarily wasteful of labour, was considered necessary by the sugar planters as a means of social control. The chief reason why planters felt it was unnecessary to change from the hoe to the plough, according to Richard Pares (1960: 23), was that the planter had labour to waste during more than half of the year. I have written elsewhere that while it was feasible from a technical and economic standpoint to use horse-drawn ploughs and harrows, actually such a move would have unbalanced the labour force. Planters, therefore, generally owned enough slaves to perform peak load tasks at crop time. They considered it dangerous to public order to idle a large proportion of their labour force during the so-called "dead-season" (Sheridan 1960: 139; Goveia 1965: 116-21).

Although implemental husbandry had little impact on the conduct of 
field work in the slavery era, a biological innovation that affected both field and factory operations in important ways was introduced into the British sugar colonies in the early 1790s. This was the Otaheite or Bourbon variety of cane which was brought from the South Seas to the French West Indies in 1789, and to St. Vincent and Jamaica in 1793. This new variety of cane, according to Baron von Humboldt, was "one of the most important acquisitions for which colonial agriculture is indebted to the travels of naturalists." He said it yielded not only one-third more juice, but it was also thicker than the old "Creole" cane and the bagasse supplied more fuel to the boiling house. It was less vulnerable to dry weather and insect pests, but, on the other hand, it exhausted the soil more rapidly and did not ratoon as well as Creole cane. Planters were quick to introduce the new canes and the resulting bumper crops probably contributed to the severity of the price decline at the end of the century (Von Humboldt 1851: I, 486; Starkey 1939: 103-9; Deerr 1949-50: I, 20-1; Bennett 1958: $7,103)$.

Pares $(1960: 24,69)$ has observed that sugar was more heavily capitalized than any other plantation industry, and that by far the greatest capital items were the value of the slaves and the acreage planted in canes by their previous labour. He noted that "with the mill, the boiling house, and the still went an army of specialists - almost all of them slave, but none the less specialists for that. They were not only numerous because of their skill, but had a high value." The shift from the employment of white to black tradesman on the sugar plantations was apparently completed during the middle decades of the eighteenth century. Extant inventories of plantation slaves seem to bear out this generalization. Of the 301 slaves on the Codrington plantations of Barbados in 1775, 21 of the men were classed as artisans. There were 3 coopers, 3 potters, 3 clarifiers, 3 distillers, 2 millmen, 2 blacksmiths, 2 basketmakers, 1 carpenter, 1 boiler, and 1 clayer. Bennett (1958: 12, 15-20,73) writes that "craftsmen, head watchmen, head carters, and skilled workers ranked with the drivers of the great gang as the chief men of the Negro community. Their importance to estates was marked by many tokens of special status." Wiliam Dickson (1789: 26), who was secretary to the governor of Barbados in the 1770s and 1780 s, noted that "so many blacks are now bred to all kinds of trades that the poor white artificers often find it difficult to get bread".

Jamaica followed Barbados in the shift from white to black skilled labour. In the early decades of the sugar industry white artisans were occasionally supplanted by their mulatto and black apprentices. In time, the planters who formerly depended upon white tradesmen found it was less costly 
to train intelligent young slaves as skilled craftsmen. "They take the hoe, the adze, the hammer, or the plane the first time into their hands with as much youthful vanity as a boy at school does his bat; and it is not long before they know how to make an ingenious use of either", wrote William Backford, the Jamaican planter historian (Beckford 1788: 14; Galenson 1981: 128-39; Craton \& Walvin 1970: 102-5, 111, 138-40).

"Of the sugar colonies", writes Barry Higman, "only Barbados experienced an absolute increase in its slave population over the period 180734 ," when it rose from approximately 75,000 to 83,150 . It was also remarkable that the island more than doubled its sugar production in the same period, and that the islanders were able to feed themselves to a large extent from local resources. William Dickson lived in Barbados during the transition from negative to positive net population growth. In his Mitigation of Slavery, he enumerated eleven reasons why the condition of the slaves was "less intolerable in Barbados, than in the other sugar colonies". Dickson argued that improved conditions prevailed in such areas as religious instruction, punishment, food supply and diet, and work loads. He noted that "in that island, the raising of provisions, for its unequalled population, is a prime object, not only with the ten-acre-men, and the white militia tenants, but with many or most of the sugar planters; and fishing is pursued with industry and success." Imported foodstuffs having been precarious during wartime and locally-grown provisions frequently inadequate, famine conditions were experienced on several occasions from about 1775 to 1807. "After the closing of the African slave trade in 1808", writes Bennett (1958: 101), "the newly formed agricultural associations brought home the lesson that the planters could no longer afford to lose Negroes to famine. When trade with the United States was almost cut off during the Napoleonic Wars, the Barbadians were prepared for the emergency" (Dickson 1969: 439-41; Watson 1975: 127-59; also Higman 1984: 50, 75, 205-14, 417-8).

Jamaica's sugar and slave experience differed greatly from that of Barbados in the half-century prior to slave emancipation in 1834. Jamaica's economy was more diversified than that of Barbados; its plantation economy grew much more rapidly than that of its sister island, especially in the period from 1784 to 1815 ; the profits of sugar production enabled a larger proportion of its proprietors to be absent from the island; and the planter elite came to be recruited chiefly from the ranks of overseers, managers, and attorneys. Jamaica's plantation economy continued to be less labour-and capital-intensive than that of Barbados. Whereas the ratio of slaves to acres of cane harvested was very near 2:1 in Barbados, it was approximately 1:1 in Jamaica where cane growing was less dependent 
upon heavy manuring and ratoons supplied a larger proportion of the harvested canes. However, some evidence can be adduced to support a contrary conclusion with respect to labour intensity. Night work during crop time continued to be common in Jamaica down to emancipation, whereas it was largely discontinued in Barbados. Moreover, Barry Higman has estimated that the typical Barbadian slave worked an average of 3,200 hours annually, compared with 4,000 hours for his or her Jamaican counterpart (Higman 1984: 54, 112, 182-8; Barrett 1965: 165-7).

In summing up the slavery era, it appears that slave labour was generally compatible with technological progress, particularly in its mechanical aspects. By taking over skilled plantation tasks which were initially performed by white artisans, the black slaves demonstrated a high degree of adaptability to changing sugar technology. Such slaves, known as "privileged slaves", were commonly allowed small perquisites by their masters. On the other hand, it is true to say that the mass of slaves were generally kept in as degraded a condition of ignorance and poverty as possible. Yet, even here, as Douglas Hall overserves, "with the aid of small and relatively cheap assessories they could work on a wide range of tasks and materials, turning the soil, weeding, cutting canes, feeding the sugar mills, packing sugar, driving cattle or building or repairing roads, mills and houses". The versatility of the mass of slaves helps to explain "the generally slow and unwilling introduction of agricultural implements, such as the plough and harrow, during slavery" (Hall 1962: 305-18). Apart from implemental husbandry, Barbados planters and slaves moved more rapidly into biological innovations and less rapidly into mechanical innovations than their counterparts in Jamaica, especially in the period from about 1775 to 1834 .

\section{III}

The slave emancipation bill was introduced into the House of Commons in May, 1833, chiefly because the abolition of the slave trade in 1808 had failed to mitigate the cruelties of slavery. Conflicts between contending interests in Westminster and the colonies had escalated into slave uprisings in Barbados, British Guiana, and Jamaica. "It was the Jamaican rebellion", writes William A. Green, "not the new vigour of the anti-slavery movement, that proved the decisive factor in precipitating emancipation." In brief, the emancipation act made the ex-slaves into apprentices to their old masters, who were required to supply them with allowances of food, 
clothing, lodging, and medical attendance. In return for their subsistence, the apprentices had to give about forty-five hours of unpaid labour each week. After meeting this requirement, they were free to work for wages. Stipendiary magistrates were employed as guardians of public order and to ensure that the apprentices obtained their legal rights. Slaveowners, both resident and absentee, were awarded compensations for the loss of their slave property to the aggregate amount of $£ 20,000,000$ sterling (Green 1976: 111-27; Turner 1982: 148-78; Beckles 1984: 86-120).

Hoping to prove that free labour could produce tropical staples at a lower cost and with greater efficiency than slave labour, proponents of the apprenticeship system regarded the survival of the plantation with its purportedly cohesive, stable, and orderly environment as a necessary means to their goal of a free labour colonial system. Among other things, the apprenticeship period would enable the planters to "introduce new equipment, to experiment with new techniques, and to revise methods of labour management". Reality, however, fell far short of the grand scheme that was envisaged, for planters were prone to cling to arbitrary powers over their blacks, who were accused of behavior that was insolent, negligent, and disobedient. "In spite of its defects", writes Green, "apprenticeship did produce better working conditions and a moderation of discipline for the labouring people, and it offered the planters a valuable cushion between slavery and full freedom. In all respects, however, the system failed to establish the firm foundation of a free society which its proponents had intended" (Green 1976: 126-7, 130-8; Green 1973: 448-73; Levy 1980: 3870).

Barbados entered the period of free labour in 1838 with a monocrop sugar plantation economy, rigid colour and class stratification, economic and political dependence on the metropolis, a largely resident planter elite, a high population to land ratio of approximately 700 persons per square mile. The transition from apprenticeship to freedom was marked by tension between whites and blacks over such issues as wage rates, ownership of cottages and gardens, vagrancy, and labour contracts. Workers who refused to work on terms dictated by their former masters were threatened with eviction. After several weeks of turmoil and idleness the workers generally returned to labour on their home estates. While the avoidance of coercion and the need to earn money to buy bread were immediate motives for returning to labour in the canefields and sugar mills, a longer-term solution was found in what is called the wage-rent or located labour system. It supplied the freedman with the security of his cottage and garden for his agreeing to give labour to the plantation upon which he resided when required. If he failed to appear for work or otherwise gave unsatisfactory 
service, he was given notice of eviction by the owner of the property, and if he refused to leave he was subject to arrest. This paternalistic and quasi-feudal system of tied workers and cottagers and compensating advantages to these workers continued with some modification down to the decade of the 1930s; it supplied the plantation owners with a cadre of low cost and combined and continuous labourers (Levy 1980: 72-9; Starkey 1939: 117-8).

The change in land use was most significant in the reorganization of agriculture in Barbados, according to William Green. Although the freedmen continued to hold gardens or cottage plots after emancipation, they seldom grew enough food for their subsistence and they no longer received rationed allowances from estate owners. Thus, they must work for wages and buy food which more and more came to be imported from the United States. "By the fifties", writes Green, "well over half the total acreage in the island was committed to sugar, and even the working people preferred to use their small cottage plots for growing the cash crop." As the acres planted in provision crops declined, those used to grow sugarcanes increased. From the statistics of British sugar imports from Barbados which accounted for all but a tiny fraction of the island's total exports before 1860 , we find that the early years of full emancipation witnessed a severe decline in sugar output owing to drought and labour unrest. Production and exports recovered slowly from 1841 to 1845 , expanded more rapidly from 1846 to 1850 , experienced a growth spurt from 1851 to 1855 , and levelled off from 1856 to 1860 . Sugar exports to Great Britain, which amounted to an annual average of 15,992 tons in $1841-45$, increased so rapidly that by $1856-60$ they were 32,087 tons annually, or double the exports of 1841-45 (Green 1976: 199-207; Deerr 1949-50: I, 193-4).

It is difficult to gauge the profability of sugar production in Barbados, owing partly to fluctuations in the price of the staple in British markets, and partly to uncertainty regarding the cost of production in the island. Governor Sir Francis Hincks (1856-62) believed the average cost had declined since emancipation, chiefly from a reduction in labourers' wages, and that the planters enjoyed relatively high profits. According to Claude Levy, "Hincks explained that the abolition of slavery had materially benefited the planters, because the expense of paying wages to each person actively at work in the fields and mills was less than that of providing every Negro with food, clothing, and shelter, regardless of whether such individuals were able to contribute any useful work." Of a contrary opinion was Henry Taylor, Senior Clerk in the West India Department of the Colonial Office, who, in reviewing Hinck's dispatches to London, "was unable to agree that intensified production had benefited the proprietors in proportion to their efforts (Levy 1980: 124-6). 
What does seem certain is that, in consequence of the Sugar Duties Act of 1836, which called for reduction and eventual elimination of the differential duties favouring the colonial product, the planters of Barbados felt that dire necessity compelled certain changes. Wages and salaries were greatly reduced, numerous proprietors took upon themselves the management of their own estates, and, as Davy explained, "a more economical system throughout was adopted with a great reduction of expenditure, even in some instances, to the amount of 40 percent." Davy expressed the hope that the crisis of $1847-48$ would generate positive action and lead to a salutary and eventually beneficial outcome. He noted "a growing disposition to view agriculture more in the light of a science, and to consider the making of sugar more as a chemical process to be directed by science". One biological innovation was the system of "wide planting", whereby the distance between the rows was increased from three or four to six or eight feet, "and with marked improvement in the size, vigor, health, and yield of the cane". Planters experimented with new types of fertilizers. Whereas pen manure with mould had been used almost exclusively in earlier years, now experiments were conducted with Peruvian guano, nitrate of soda, soot, and imported manures. Guano was first applied to the canefields in 1846, and by the mid-fifties the Barbados planters led all others in the use of this bird dung which was imported to the average value of $£ 50,000$ a year. Trashing or mulching the growing cane plants with leaves obtained from the former crop was more widely practiced for the purpose of retaining moisture in the soil, checking the growth of weeds, and promoting the growth of canes. By paying the worker by the job or task, such as weeding a cane piece, it was said that he or she could complete in six hours the amount of work that had formerly required twelve hours for a slave (Davy 1854: 115-6, 142-4; Green 1976: 202; Sewell $186151)$.

Implemental tillage came to supplement and in some cases supplant - cane hole agriculture in Barbados. Owing to ample supplies of cheap labour to perpetuate their garden-type cultivation, Barbadian planters were slow to introduce animal-drawn instruments of husbandry. Davy said the use of the plough was not resumed until 1839-40, and then only partially. By the early 1850s he said it was still far from being generally in use. Later in the same decade William Sewell, the New York journalist, found on his visit that the Barbadians, after long hesitation, had at length introduced the plough, "though some few fogies, as fossiliferous as their own rock, still question the safety of the innovation" (Davy 1854: 114; Sewell 1861: 59).

Although Barbados was in the vanguard in adopting the new biological 
technology, it lagged behind the other sugar colonies in introducing mechanical technology. The Barbadians were slow to substitute steam enigines and improved mills for windmills, for we have seen that as late as 1846 there were 506 windmills and only one steam mill. This state of affairs was investigated by the Committee on Sugar and Coffee Planting in the Colonies. George Carrington, an absentee proprietor who had returned from the island one year previous testified in March 1848, that there were three or four steam-mills in Barbados. He told of having recently sent out a horizontal steam-mill for grinding the canes on his own plantation. His goal was to shorten the crop time, guard against the uncertainty of the wind, and realize considerable saving by being able to reap his crop precisely when it came to maturity. Unfortunately, and for reasons he did not reveal, Carrington "incurred the expence of upwards of a thousand pounds in effecting that which I now feel may be entirely thrown away". Anthony Trollope noted on his visit to the West Indies in 1859-60, that in Barbados "not one planter in five, not one I believe in fifteen, has any steam appliance on his estate. They trust to the wind for their motive power, as did their great-great-grand-fathers."

Besides the cane crushing mills, the boiling and curing houses of Barbados were the scene of experiments with the new sugar technology. Dr. Davy (1854: 144-6) wrote with enthusiasm of the installation of vacuum pans, Gasden-pans, precipitators, and centrifugal dessicators which he claimed were coming rapidly into fashion. At the time of writing in the early 1850s, he said that four vacuum pans had been installed in the island and that, under careful and skilled management, there had been a gain of 25 percent.

A project to construct a railway in Barbados was conceived in 1845 by a group of British promotors headed by Sir Robert Schomburgk. Although the chief revenue was expected from passenger traffic, the railway was intended to serve the needs of the plantations by providing cheaper and more expeditious transport than that of the animal-drawn vehicles in the carriage of sugar from the interior to the ports. The railway project failed because of the shortage of local capital and the unwillingness of the British government to make a loan to Barbados (Schomburgk 1848: 185-8, 527-8; Levy 1980: 100).

\section{IV}

The decline of Jamaica's sugar industry long antedated the freeing of the slaves. From the period of the American Revolution the planters were plagued with trade embargoes, hurricanes, droughts, threats of slave 
insurrections, fluctuating costs and prices, and alternating periods of high and low profits and not infrequent losses. Abolition of the transatlantic slave trade foreclosed the customary means of maintaining or expanding the labour force and added to costs of staple production. The high point of sugar production was in the quinquennium 1801-05, when an annual average of 86,640 tons of sugar was imported into the British Isles from Jamaica. By 1831-35, the imports had declined to 65,896 tons annually, after which they fell precipitously to 22.943 tons in $1856-60$, or by nearly two-thirds of the 1831-35 figure. Based on raw sugar prices in London, the annual average value of sugar imports from Jamaica was $£ 1,910,984$ sterling in $1831-35$, and $£ 620,703$ in 1856-60. The most remarkable thing is that while the sugar imports from Jamaica exceeded those from Barbados by nearly 50,000 tons annually in $1831-35$, by the early 1850 s the imports from Barbados had overtaken those from Jamaica and were approximately 9,000 tons greater annually in the 1856-60 period. Jamaica's exports of rum and coffee, of which the United States and Canadian markets took off considerable quantities, declined in roughly the same proportions as that of sugar (Deerr 1949-50: I, 193-9; II, 531; Hall 1959: 39).

Numerous writers sought to explain the decline of Jamaica's sugar industry. Looking back from his vantage point in the early twentieth century, Lord Olivier (1971: 131) believed that " $[t]$ he most obvious causes that undermined the old sugar economy and hindered its readjustment to the new conditions were absenteeism, reactionary overseers, obsolete technical methods, the excessive burden of mortgages, profligate soil exhaustion, the attempt to coerce labour at low wages by unfair rents, and access by labourers to unoccupied land", John Bigelow (1851: 7982 ), the American journalist who visited Jamaica in 1850 , was informed that nine-tenths of the land under cultivation before the Emancipation Act was owned by absentee proprietors and that that proportion had not diminished materially. He asserted that it was the tendency of absenteeism "to drive from a country its intelligence, its ingenuity, and its patriotism". To W.G. Sewell (1861: 237, 276), absenteeism was "the most prominent among a host of evils", since it exhausted capital, destroyed credit, and led to the abandonment of many sugar estates.

Absenteeism and mortgage debt went hand in hand. In former periods of prosperity and buoyant optimism absentees had borrowed money on the security of their estates to support extravagant lifestyles and provide annuities and marriage portions for family members. Subsequent periods of declining prices and profits found the estates to be mortgaged for more than they were worth. John Bigelow discovered "from the most authentic and reliable sources" that there was "scarcely an estate upon the island 
which is not mortgaged, or which has not been sold under a mortgage sale". The heavy debt burden, in turn, left Jamaican planters and agents with little or no means or capital to carry on the cultivation and manufacture of sugar (Bigelow 1851: 113-4). To the Jamaican planter the chief cause of decline was the high cost and uncertain supply of labour. Planters told W.G. Sewell that the emancipated blacks were "too independent, too well off here - too fickle, arbitrary, and uncertain as to when they will work and when they will not work. They just do as they please." The planters insisted that the black would not work longer than was necessary to supply his meagre standard of living. The blacks, on the other hand, complained that the planters were too poor to pay, or that they did not pay regularly. Actually, the typical freedman aspired to a higher standard of living than had prevailed in slave days. He was attracted to the considerable tracts of idle estate land that were available for as little as $£ 4$ to $£ 10$ an acre, but he was willing to work for wages on the estates for three or four days a week in order to provide the means to vary his family's diet with imported foodstuffs and to buy clothing and other consumer goods (Sewell 1861: 186, 193; Eisner 1961: 191-5, 210-6; Hall 1959: 15-20; Marshall 1968: 252-63).

Planters sought to retain labourers on their estates by charging high rents for the use of huts and provision grounds and by discouraging the sale of idle land to the freedmen. However, in the face of the exodus of labourers from the estates, the planters found it necessary to retreat from their aggressive policies. Due partly to some progress in resolving disputes regarding wages and rents, partly to schemes for immigrant labour, and partly to the introduction of labour-saving innovations, the sugar industry of Jamaica experienced considerable advance from the early 1840s until 1846. According to Douglas Hall, the reduction of the agricultural labour force induced planters "to attempt to maintain the volume of production by substituting animal and mechanical power for human effort, and to increase productivity of the remaining labourers". Although capital and credit were severely limited, a few planters benefited from the relatively high sugar prices from 1836 to 1842 , and a larger number received slave compensation money which generally improved their credit standing in Britain, at the same time that it was swallowed up in debt repayment (Hall 1959).

Full emancipation in 1838 saw heightened interest in scientific agriculture and the adoption of biological and mechanical innovations. The Royal Agricultural Society of Jamaica, together with similar societies in separate parishes, held agricultural fairs and exchanged information on such subjects as soil chemistry, fertilizers, implemental husbandry, animal husbandry, 
cane diseases and pests, and successful innovations in manufacturing processes. Ploughs, harrows, and horse-hoes were widely adopted, especially on level cane fields that were free of obstructions and possessed of light soils. Local craftsmen developed rugged and deep-cutting instruments that were adapted to heavy and compact soils. These animal-drawn implements enabled cane rows to be spaced more widely and made weeding easier. From his study of the various contemporary reports on the use of the plough and harrow, Hall calculates that these implements reduced the labour costs of planting and cultivation per acre by about 65 percent. To increase the yield of the cane fields, cattle manure was supplemented by such island fertilizers as lime, ashes and seaweed, and such imported fertilizers as bone-dust and especially guano (Hall 1959: 27-32, 46-50, 57, 63, 66; Green 1976: 52-4, 199-200).

The period of optimism in the post-emancipation period saw the adoption of improved mechanical technology. Cane crushing mills gained power and certainty by the substitution of steam power and water power for cattle and wind. Hall says that although the small steam-powered mill did not appear to have any great advantage over a well-built water mill with a dependable flow of water, "both these types were immeasurably superior to wind mills and far better than animal mills". "By 1854", he writes, "just over two-thirds of all sugar mills in the island were driven by steam or water, and just under one-third by steam. This is clear evidence of widespread attempts to improve manufacturing methods." Although small improvements were made in the boiling and curing of the cane juice, such new technology as the vacuum pan was so costly and the labour supply so uncertain that only three estates had installed this equipment by the mid-century period (Hall 1959: 69-76).

Transportation and central factory projects were launched to bridge the gap between cultivating and processing to amalgamate estates and have one large factory serve a whole cane-growing area. While the South Midland Railway and the Clarendon Tramway projects failed to materialize, the thirteen miles long railway from Kingston to Spanish Town was opened in November 1845. In the following year two proposals were put forward to establish central sugar factories, but they failed to materialize (Hall 1959: 35, 38-40, 59-60, 85-93; Eisner 1961: 198-200).

The Sugar Duties Act of 1846 served as a watershed between the period of optimism and innovation and that of pessimism and retrenchment. In the new climate of pessimism and retrenchment, the new sugar technology was found to be less widely adopted than was formerly thought and its merits and demerits more soberly assessed. Bigelow asserted that there 
was an "entire neglect of the most obvious methods of economizing labor", while Sewell claimed that the typical Jamaican planter practically ignored all the agricultural and mechanical improvements of the century. Ploughs and harrows were reported to have improved the system of cultivation generally, but they were far less widely adopted than was formerly thought, they required large numbers of draft animals to work them, they were frequently broken on the rocks and rendered useless for want of tradesmen to repair them, and they were costly to operate by ploughmen who were brought out from Europe. Hall Pringle, a Jamaican planter, claimed that very few planters and their hired managers knew anything of the art of ploughing. "White ploughmen in most cases met with a speedy death from fevers, the consequence of their employment under a tropical sun", he wrote. "It was found, however, that the negroes could be very soon converted into expert ploughmen. Nevertheless, this slight improvement in West Indian agriculture made scarcely any progress, and for the most part the use of the plough was abandoned in Jamaica; though the plough has continued to be employed in some other West Indian colonies with great success" (Bigelow 1851: 129-37; Sewell 1861: 274-5; Pringle 1869: 14-5).

Jamaican planters claimed that they were avidly interested in scientific agriculture and said that special attention was given to experiments with imported fertilizer, notably guano. Yet, they were slow to exploit a source of this bird dung that was close to hand and much cheaper than far distant supplies. Rich deposits of rock guano were discovered on the Morant and Pedro Cays, lying thirty to fifty miles south of Jamaica and governed from that Colony. They were first exploited by North Americans and much later by Jamaicans (Green 1976: 199-200; Beachey 1957; 88).

Improved machinery for the sugar works was not only expensive and difficult to procure in a period of capital and credit stringency, but there was an acute shortage of first-class tradesmen to install, operate, and repair the machinery. The establishment of central factories presented insurmountable difficulties after 1846, including lack of cooperation among proprietors and their creditors, limited areas where sufficient level land was available, lack of cane farmers to grow canes for the factory on a contract basis, and the heavy mortgage indebtedness and claims by annuitants on the annual revenue of plantations. Similar problems were encountered in building light-gauge railways or tramways in Jamaica. ${ }^{6}$

Jamaica's labour problems worsened after 1846, chiefly because the planters found it increasingly difficult to offset the freedmen's attraction to independent settlement by offering sufficiently high wages and other favourable conditions of employment. Planters complained that the freed- 
men were too independent to work for wages or that they refused to work more than five to six hours a day and four to five days in the week. Moreover, at critical seasons, the freedmen were charged with leaving an estate almost deserted to plant or look after their own provision grounds. The freedmen, on the other hand, complained that the planters would not give continuous work at continuous wages, and that they were too poor to pay or that they frequently delayed wage payments. Given the labour problems, limited gains in productivity, heavy debts, and absenteeism, it became obvious that many plantations could not hope to continue in production. The number of sugar plantations in Jamaica reached a peak of 859 in 1804. Thereafter, they declined to 646 in 1834, 513 in 1846, 330 in 1854, and 300 in 1865 . Between 1834 and 1865 some 346 sugar estates were abandoned. Gisela Eisner says that "many of them were uneconomic in the sense that they had been profitable only as long as labour mobility could be restricted, and hence wages controlled." As the number of sugar estates declined, the number of black peasants increased. The estimated number of peasants, that is, freedmen who held some land either as purchasers or squatters, increased from at least 30,000 in 1846 to 50,000 in 1860 , and to 60,000 in 1866 (Sewell 1861: 186, 279-4; Hall 1959: 81-3; Eisner 1961: 203, 215-6).

\section{$\mathrm{V}$}

British West Indian planters and labourers were confronted with a host of problems in the years from 1860 to 1900 . Jamaicans were especially hard hit at the beginning of the period by poor crops, low and irregular wages, and the high cost of imported foodstuffs during the American Civil War. Peasant discontent escalated into an outbreak of disorder and bloodshed at Morant Bay, Jamaica, in October 1865. British sugar planters met with growing competition in United Kingdom markets, especially beginning in 1874 when sugar duties were completely removed. The situation worsened as European nations dumped more and more bounty-fed beet sugar into United Kingdom markets. The price of sugar declined below the cost of production on many estates, resulting in genuine distress. At a time when London sugar prices were plummeting, those prevailing in the United States and Canada fell less severely and attracted increasing quantities of sugar and other products from the British Caribbean colonies. Notwithstanding the growth of alternative markets, the sugar industry was in such dire straits that in 1897 a Royal Commission was appointed "to enquire into the conditions and prospects of the sugar-growing Colonies 
in the West Indies and to suggest means calculated to restore and maintain the prosperity of those Colonies". We shall see that the Commissioners found that the economies and societies of Barbados and Jamaica were following divergent paths, the former continuing to concentrate practically all of its resources on the production of sugar and its by-products, while the latter was in the process of shifting the greater part of its resources to the production of subsistence crops and agricultural staples other than sugar. ${ }^{\text {pr }}$

Noel Deerr has tabulated the West Indian sugar production of the different colonies to demonstrate the overall effects of emancipation and of the adoption at a later period of free trade. Table 2 shows the contrasting change over time of sugar production in Barbados and Jamaica.

Table 2: Average Annual Sugar Production of Barbados and Jamaica, 1824-1896 (in tons)

\begin{tabular}{lllllllll}
\hline & $1824-33$ & $1834-38$ & $1839-46$ & $1847-56$ & $1857-66$ & $1867-76$ & $1877-86$ & $1887-96$ \\
\hline Barbados & 14,838 & 20,309 & 15,652 & 28,622 & 36,367 & 40,358 & 46,260 & 54,667 \\
Jamaica & 68,465 & 54,225 & 33,431 & 27,474 & 25,168 & 25,666 & 21,571 & 20,891 \\
\hline
\end{tabular}

Source: Deerr, 1949-50: II, 377.

If we compare the 1847-56 period with that of 1887-96 in Table 2, we see that while the sugar production of Barbados nearly doubled, that of Jamaica declined by nearly one-fourth. Barbados' extreme sugar monoculture is demonstrated by a table in the Royal Commission Report which shows that the collective export value of sugar, rum and molasses from that island was 98.0 percent of total export value in the 1887-96 period. Another table shows that while the share of the island's total exports to the United Kingdom declined from 50.7 to 5.8 percent from 1887 to 1896 , the United States' share increased from 22.3 to 70.8, and that of Canada and other countries declined from 27.0 to 23.4 percent in the same period. On the other hand, Jamaica's collective value of sugar, rum and molasses exports declined from 77.2 percent of total exports in $1881-82$ to 19.2 in 1895-1896.

The island's share of total exports to the United Kingdom declined from 60.2 to 13.8 percent from $1881-82$ to $1895-96$. In the same period the exports to Canada and other countries declined from 31.5 to 3.8 percent, while those to the United States increased from 8.3 to 82.4 percent. $^{8}$

The sugar economy of Barbados was thoroughly investigated by the Royal Commission during its stay on the island from 16 to 24 February, 
1897. "In Barbados there is substantially but one industry, one product, and one export - that of sugar - nor does the Island appear to be suited for the growth of either coffee, cocoa, or fruit on a scale of any commercial importance", said the Report of the Commission. At the time of the visit Barbados had an estimated population of 186,000 , giving a density of 1,120 to the square mile, compared with the 1844 population of 122,200 and density of 740 persons per square mile. The number of sugar plantations, which had been relatively stable at about 500 from 1860 to 1890 , declined to 440 in 1897. The average size of plantations increased from 179 acres in 1860 to 206,5 acres in 1897 . In the latter year there were 23 plantations over 500 acres, 175 from 201 to 500,103 from 101 to 200 , and 138 less than 100 acres. The acreage in cane remained constant at roughly 90,800 acres from 1890 to 1897 . In the latter year muscovado sugar was produced on 94 percent of the plantations and centrifugal sugar on the remaining 6 percent. $^{9}$

Innovations in biological technology played a part in saving the sugar industry of Barbados and other sugar colonies from possible destruction. Beginning in 1891, the yield of the Otaheite or Bourbon experienced rapid decline as the result of a fungus disease. Fortunately, as R.W. Beachey points out, the Government of Barbados had appointed an agricultural chemist, who, with the assistance of his colleague and the cooperation of the local agricultural society, did much to prevent the spread of the disease and to introduce new varieties. By 1897 , following the development of a new variety called White Transparent, the planters of Barbados had the cane disease under control. Other experiments were conducted on the effect of fertilizers - both farmyard and artificial - on the yield of sugarcanes. Barbadian planters took advantage of the great reduction in the price of imported fertilizers, especially sulphate of ammonia, to apply them in greater quantities, with a reported increase in crop production of 15 percent in the decade ending in 1897. On the other hand, there was no innovation of modern tillage introduced on the sugar estates of the British West Indies during the second half of the century and the plough was still rarely used (Beachey 1957: 89, 92-3; Starkey 1939: 124-6, 153-6; Hoyos 1978: 1736).

Improvements in the manufacture of sugar were not extensive during the later decades of the nineteenth century. When the Royal Commission enquired about recent improvements in the production of sugar, the Joint Committee of the Agricultural Society and Mercantile Body of Barbados replied in a written communication that "steam machinery has during the last 30 years been more extensively employed for crushing, and has no doubt effected some considerable saving by reason of the greater 
reliability of its operation as compared with wind power." From 30 steam mills in 1866, the number increased to 49 in 1875,90 in 1884 , and 102 in 1896. The number of windmills in 1896 was about 338. "Eight plantations, aggregating some 5,000 acres, have vacuum pans, but these were all erected prior to 1884," said the Committee Report. Owing to the imperfect crushing of the canes in the mills, it was stated that 13.6 tons of cane were required to produce one ton of sugar in Barbados, whereas the best machinery would require only 9.5 tons of cane to one ton of sugar. Similarly, imperfect boiling and curing of the cane juice resulted in a substantial loss in the amount of muscovado sugar that was recovered. ${ }^{10}$

Among the numerous reasons for the failure to modernize the Barbadian sugar industry, two are of paramount importance. The severe decline in sugar prices beginning in 1884 brought real hardships to the planters and their dependents. The Royal commission learned that while some estates in favourable situations and with favourable seasons might just make a profit at prevailing sugar prices, others were being worked at a loss. As a rule, the estates were very heavily mortgaged and it was increasingly difficult to get advances to carry on cultivation. In particular, it was difficult to raise money on the plantations for capital improvements. Although a large majority of the plantations were heavily encumbered, it was stated that these incumbrances had not diminished production or checked the expansion of the industry. On two occasions between 1884 and 1896, Barbadian planters attempted to secure government loans to build central factories. They were "turned down by the Colonial Office on the ground that they were unsound, considering the state of colonial finances, and that unless a first charge on the estate was given as security, the Colonial Government must not enter into such speculation. Estate owners were usually agreeable to giving this first charge, but mortgagees were not." 11

The generally prosperous state of the plantations down to the mid-1880s was the second paramount reason for not modernizing the island's sugar industry. The Royal Commission noted such special circumstances prevailing in Barbados as the more abundant and effective labour supply and a soil that was especially well suited for growing sugarcane with exceptionally rich juice. The Joint Committee of the Agricultural Society and Mercantile Body of Barbados stated that large factories had not been erected in former prosperous times because "the profits derived from muscovado sugar were so good that the proprietors of plantations were content, and had no motive arising from a felt necessity for adopting improved machinery."12

The Royal Commission enquired as to the conditions of labour, its cost and efficiency, access to provision grounds, cost of living, and related 
matters. The Agricultural Society and Mercantile Body said that labour was plentiful, fairly efficient, supplied at a moderate cost, and that most operations were done by piece-work. Wages amounted to $5 \mathrm{~d}$. per day for children under $16,71 / 2 \mathrm{~d}$. for agricultural women, $10 \mathrm{~d}$. for agricultural men, and $2 \mathrm{~s}$. for mechanics. A great many women and children were said to be employed on the plantations. One planter was asked if there was any system by which mechanics could become efficient workmen. He replied: "The apprenticeship system is in a sadly decaying condition now. Formerly it was flourishing." Concerning the "peasant" sector of the Barbadion economy, it was reported that approximately 4,500 of the total acreage of the plantations was rented to agricultural labourers, but that few of them grew their own food. Additionally, there were about 8,500 freehold owners of five acres and under who chiefly grew cane and ground provisions. Since they seldom made a living out of their land alone, they were also self-employed as shopkeepers and artisans. The cost of living was said to be very small and food cheap. ${ }^{13}$

That the labouring people of Barbados bore the brunt of the sugar depression of the late nineteenth century is amply documented by the evidence submitted to the Royal Commission of 1897. The Reverend J.E. Payne, Wesleyan minister in the parish of St. Philip, considered the condition of labouring people to be "one of extremely great poverty, demoralising in its effects, and presenting very serious difficulties in the way of their moral advancement and enlightenment." To support this statement he called attention to their overcrowed, comfortless homes that were prejudical to the maintenance of morality and sanitation; their food which consisted almost entirely of vegetable and was insufficient to maintain a working man in health and vigour; their children who were kept from school and church for want of clothing; their frequent and distressing appeals for charitable relief. Payne considered "that the wages obtained by the labouring people (from $2 \mathrm{~s} 6 \mathrm{~d}$. to $5 \mathrm{~s}$. a week, out of which they have to pay the rent for the small plots of land on which their houses stand) are not sufficient for their maintenance." C.E. Gooding, M.D., a parochial medical officer, submitted evidence showing the increase of pauperism in Barbados of late years and the high and growing death rate. He said that many islanders found it "difficult to keep soul and body together at any time, but in periods of drought (to which our seaboard districts are very liable) the number of these is vastly increased, and their privations extreme". During the harvest season when work was at its height and the demand for labourers satisfied, "crowds of unemployed, both young and old, of both sexes, lounging from place to place, both in the city and country districts for want of employment", was the condition reported 
by J.F. Clarke, M.D. Mr. T. Henri Field called attention to the deep feeling of unrest among the labouring population of Barbados and warned that any further reduction of the rate of wages would possibly precipitate social disorder. ${ }^{14}$

Jamaica's sugar industry, which continued to decline down to the outbreak of World War I, was unable to support the island's growing population. From approximately 371,000 at the time of slave emancipation in 1834, the population of Jamaica increased to 694,865 in 1896 , or an increase of 87 percent, in a period of approximately sixty years. We have seen that the number of sugar estates in Jamaica declined from 646 in 1834 to 300 in 1865 . Thereafter, the decline continued at an even more rapid rate.

There were 266 estates in 1869,244 in 1875,202 in 1880, 162 in 1890, 140 in 1896,111 in 1900 and 74 in 1910. According to the Report of the Royal Commission of $1897-8$, the area under cultivation in sugar cane in Jamaica in 1896 was 30,036 acres, equal to 16.4 percent of the land under crops in the colony, or to 34 percent of the land producing exportable crops. Of this average, 24,972 was cultivated by the workers on 140 sugar estates, and 5,064 by small settlers on their own properties. The majority of the estates were small (the average area in cane being only 178 acres) and they were also, for the most part, widely dispersed. Steam-power was employed on 95 estates, waterpower on 38, water and steam on 3 , and cattle on 4 . Of the 140 sugar estates, six had vacuum pans, and the rest were "worked with open batteries, assisted in the great majority of cases, by evaporating pans, of various kinds and centrifugal machines". Seventy percent of the estates produced centrifugal sugar; the other thirty, raw or muscovado. Rum was distilled on 98.5 percent of the estates. The average crop of sugar was 23,492 tons, and the average crop of rum was 20,448 puncheons of 100 gallons each.

One measure of the slow progress that was made in modernizing the sugar industry is the average output of the sugar factories of Jamaica by comparison with those of British Guiana. In the period, 1880-1900, the number of factories in Jamaica declined from 202 tot 111, while the average output in tons of sugar rose from 148 to 187. In British Guiana, the number of factories declined from 105 to 46 from 1885 to 1904 , while in the same period the average putput rose from 914 to 2,320 tons of sugar. As late as 1930, the 39 factories in Jamaica had an output of only 1,572 tons. In contrast to Jamaican estates, those in British Guiana converted rapidly to multiple-effect evaporators after 1884 with a massive reduction in production costs. British Guiana also gained on Jamaica by drawing on much larger supplies of indentured immigrants from India (Eisner 1961: 302; Adamson 1972: 188-99). 
Much of the reorganization of the sugar industry of Jamaica was undertaken by the West India merchants of London, of whom a considerable number became proprietors in their own right. These partnership firms had intimate knowledge of the island's sugar industry from their long established mercantile, shipping, and financial connections. They took advantage of the West India Encumbered Estates Court which was established in 1861 , to make out an indisputable title to any would-be purchaser of West Indian estates which were heavily ancumbered by charges placed on them in the heyday of the sugar industry. Beachey says that "the improvements that were made in Jamaica in the matter of installing centrifugals and open steam pans were mostly effected by the merchant firms who had acquired holdings through the Encumbered Estates Court". By 1897,48 of the 140 sugar estates in Jamaica were equiped with centrifugal separators (Beachey 1957: 1-4, 6-8, 17, 36,72-3, 123-4; Pringle 1869: 30; Eisner 1961: 202, 295-303).

Had it not been for the sustained demand and high price of the superior quality rum that was distilled in Jamaica, it is likely that the mortality of the sugar estates would have been higher than it actually was. Rum was produced on 138 out of the island's 140 estates in 1896. "By the end of the century", writes Beachey, "when sugar prices had dropped and the reputation and price of Jamaica rum remained high, it was held by Jamaican planters that sugar was but a by-product to the main industry of manufacturing rum". ${ }^{16}$

The Sugar Planters Association of Jamaica submitted written evidence to the Royal Commission regarding the state of the island's sugar industry. It was conceded that "the introduction of new machinery on some estates would assist in reducing the cost of production". However, the small estates, which were the rule in Jamaica, "could not afford even under favourable circumstances to employ the most perfect machinery and appliances. The outlay and small acreage of cane land would not justify it." Furthermore, the statement of the Planters Association said that "an amalgamation of estates in some districts might be possible, in which case the modern plant might be installed, and be warranted by a given acreage of cane land, and with proper management effect a considerable saving". ${ }^{17}$

The rise of the Jamaican peasantry is a fascinating story which merits a brief account of its progress down to 1900. Emancipation enabled freedmen to expand and diversify the production of their smallholdings which, in many cases, they had formerly cultivated as slave provision grounds. After about 1865, there emerged a "new peasantry" which shifted from mainly subsistence farming to both subsistence and export crop production, chiefly fruit crops. By the late decades of the nineteenth century 
the fruits grown for export consisted of bananas, coconuts, oranges, grapefruit, shaddocks, tangarines, limes, pineapples, and tamarinds (Eisner 1961: 170, 210-217; Marshall 1968: 256-257; Pringle 1869: 26, 43-44).

The fruit trade between Jamaica and the United States commenced in 1868. It was first carried on by merchants in the coastal towns who dealt directly with peasant growers. By the 1880 s companies had been organized, of which the great majority of the shareholders were small peasant proprietors, storekeepers, and artisans. "By the early 1890s", writes Hall, "there were more than one hundred banana plantations, distinct from small peasant cultivations. Many of these had once been sugar estates, but it was still the new proprietary body who dominated the new cultivation." The Royal Commission reported in 1897 that the fruit trade in Jamaica "is now the means of circulating nearly 500,000 £ annually amongst all classes of the community, and this large sum is immediately available in establishing other and more permanent industries". ${ }^{18}$

Furthermore, the Royal Commission noted that there were 30,036 acres under sugar cultivation in Jamaica; "but whereas most of the other Colonies are almost entirely dependent on sugar-cane, Jamaica produces besides coffee, logwood, bananas, oranges, pimento, ginger, cocoa, cocoanut, tobacco, and other articles of export, the value of which, as shown in the returns of 1895-96, amounted altogether to about 1,415,000£, as against $360,059 \mathrm{f}$, the value of the exports of sugar, rum, and molasses".

Jamaica was therefore in a better position to meet the falling off in the sugar trade than any of the other West Indian Colonies, with the exception of Grenada which had abandoned sugar except for local consumption, and was supporting itself entirely by other products. ${ }^{19}$

The Royal Commissioners, in their Report of 1897-8, were impressed by the achievements and standard of living of the Jamaican peasants. After holding public sittings for five days, examining 63 witnesses, and visiting outlying parts of the island they concluded that "there was a tendency on the part of some witnesses to dwell on the depressed state of the Jamaica peasantry, but there is little doubt that the bulk of them are in a position which compares not unfavourably with that of the peasantry of most countries of the world". On the whole they found "no ground for despondence as to the future of Jamaica, either in view of the possible failure of the sugar industry or on general considerations, but it is most desirable that the settlement of the people on the land should be encouraged". During their stay in Barbados, the Commissioners interrogated the Reverend C.T. Oehler, a Moravian missionary who had lived in Jamaica and was then living in Barbados. He was asked if the condition of the people in Barbados was worse than it was in Jamaica. He replied, "I 
think it is. Kingston is by no means as overcrowded as this town [Bridgetown], and the people of the country districts of Jamaica are better off than the people here, because they can get many things to eat free that cannot be obtained here except for money." He was asked, "What are the things found in Jamaica and other places fit for consumption?" He replied that nearly the year round mangoes and oranges could be found. Furthermore, he said, "In some districts in Jamaica almost any one can have a piece of land if he wishes it, and he can cultivate it for his own benefit. Here firewood has to be purchased, but in Jamaica it can be obtained only for the cost of gathering it."20

\section{VII}

This article has examined the pattern and direction of technological change in the sugar industry of the islands of Barbados and Jamaica from 1750 to 1900 , together with the impact of such change upon the slave and free workers engaged in the production of sugar, rum, and molasses. Since the typical plantation combined cane growing with the manufacture of muscovado sugar and rum, a distinction is made between biological technology by which plant and animal production was improved by increasing the effective supply of nutrients, and mechanical technology by which non-human power was substituted for human and animal power. It has been argued that in the slavery period Barbados developed a capitalintensive, power-intensive, and labour-intensive system of sugarcane agriculture and the manufacture of muscovado and clayed sugar and rum that was conducted on a sustained-yield basis. While the island's mechanical technology which was powered largely by windmills remained essentially unchanged, innovations in biological technology consisted chiefly of cane hole agriculture, heavy manuring, crop rotation, and the introduction of a new variety of sugarcane. Barbados was the only sugar colony which experienced an absolute increase in its slave population over the period 1807-34, during which time the island's sugar production more than doubled and the islanders were able to feed themselves to a large extent from local resources. Barbados was also in the vanguard in training specialist slaves to man the mills, boiling houses, curing houses, and distilleries on the estates.

Jamaican sugar planters in the slavery period practiced a land-intensive system of cane growing that, by comparison with Barbados, was less labour and capital-intensive and less dependent upon heavy applications of manure. A major biological innovation was the introduction of Guinea grass from 
Africa which supported a pastoral economy which was to a large extent integrated into the sugar economy. Jamaicans were more prone to experiment with mechanical technology than their counterparts in Barbados, but little progress was made in substituting mechanical for human and animal power in the slavery era. Sugar slavery was generally harsher in Jamaica than in the older sugar colonies, partly because the slaves were expected to feed themselves from their provision grounds. As the slave population declined after 1807 , the proportion of female field hands increased, but at a severe cost to the birth rate. Thus, the labour productivity of the sugar plantation was maintained at the expense of reproduction of the slave labour force.

After slave emancipation in 1838 , the two islands followed divergent paths. Barbados continued on its monocultural path,again with emphasis upon biological technology to a much greater degree than such mechanical innovations as steam power, vacuum pans, and centrifuges. The biological innovations consisted of the wide planting of the rows of canes; heavy applications of local and imported fertilizers, especially guano; the trashing or mulching of the growing cane plants; and the development of new varieties of sugarcane. During the later decades of the century the plight of the sugar planters worsened as European nations dumped more and more bounty-fed sugar into United Kingdom markets. The Barbadian planters' efforts to compete took the form more of wage cuts than costsaving technology. Unlike British Guiana and Trinidad where the competition of imported contract labourers forced the freedmen to work harder and for less money, in Barbados access to land and other local resources was largely shut off so that the freedmen were prevented from developing alternative source of livelihood. "In effect", writes Sidney Mintz, "the planter class sought to re-create pre-emancipation conditons - to replace the discipline of slavery with the discipline of hunger" (Mintz 1968: 70).

Jamaica's sugar industry declined dramatically from 1834 to 1900 , as a result of such factors as absenteeism, heavy debt burdens, soil exhaustion, obsolete technical methods, attempts to coerce the labour of freedmen at low wages, and the access of labourers to unoccupied land. However, the latter decades of the century saw improvements as estates came to be owned and directed by London sugar merchants who introduced laboursaving technology and produced centrifugal sugar and high quality rum. As the island's sugar sector declined, the number and importance of the black peasants increased. From the part-time peasants of the decades immediately following slave emancipation, there emerged a new peasantry in the later decades of the century which produced a wide range of articles 
of local consumption and export that were valued at more than four times the produce of the sugar estates. The economy of Jamaica thus became more diversified and much better able to meet the decline of the sugar industry than Barbados and the other sugar colonies, with the exception of Grenada. Furthermore, as Richard Lobdell has observed, "in general it is concluded that peasant organized production is more conducive to overall economic development because incomes are distributed in a more egalitarian fashion, because social stratification is less rigid, and because political institutions are more responsive to local needs" (Lobdell 1987: 30).

\section{Notes}

1. I am indebted to Professor Fogel for permission to quote this extract from his forthcoming book.

2. Journals of the House of Assembly, Jamaica, Vols. VI-X.

3. Ibid., Vols. VI-X. For a discussion of improvements in sugarmill technology, see Deerr 1949-50: II, 534-95.

4. Dr. John Davy was the brother of Sir Humphrey Davy.

5. Accounts and Papers (Parliamentary Papers), House of Commons, "Select Committee on the Condition of Sugar and Coffee Planting in the Colonies, 1847-1848," XXIII, Third Report, 11218, 11264, evidence of Carrington; Deerr 1949-50: II, 552-3; Trollope 1860: 145.

6. Beachey 1957: 81-6, 91; Eisner 1961: 202-3; "Select Committee on Sugar and Coffee Planting," XXIII, Third Report, 28 February 1848, 4536, 4537, evidence of De Walden; Pringle 1869: 29-30; Lobdell 1972: 39-46.

7. Accounts and Papers (Parliamentary Papers), House of Commons, "Report of the West India Royal Commission," 1897-98, Vol. L.

8. Ibid., Vol. L, Part II (ii), 257; Part III, Appendix B, 214; Vol. LI, Part XIII, Appendix A, 393, 401 .

9. Ibid., Vol. L, Part II (ii), 209, 212; Part III, Appendix B, 214; Barrow 1982: 85, 9192.

10. Report of the West India Royal Commission, 1897-98, Vol. L, Part III, (182), Question 5; ibid., Part III, Appendix A, (109).

11. Ibid., Part II (ii), 217; Part III, (182), Questions 1, 6 and 7; Beachey 1957: 25-26, 3334,83 . 
12. Report of West India Royal Commission, 1897-98, Vol. L, Part II (ii), 248; Part III, (182) Question 3.

13. Ibid., Vol. L, Part III, (182), Questions 9 and 11.

14. Ibid., Vol. L, Part III, (226), (237), (242), pp. 602-18. For an account of the poverty of the labouring classes of Barbados at the time of the Confederation Riots of 1876, see Belle 1984: 1-34.

15. Report of the West India Royal Commission, Vol. LI, Part XII, (477), (478), (479); Part XIII, Appendix A, (392), (393), (394), (397); Appendix C, (739), (750), (752); Beachey 1957: 123; Eisner 1961: 203.

16. Report of the West India Royal Commission, Vol. LI, Part XIII, Appendix A, (394), (397); Beachey 1957: 74-6; Eisner 1961: 298-300.

17. Report of the West India Royal Commission, Vol. LI, Part XIII, (319, (320), (321); Vol. LI, Part XIII, appendix C, (754).

18. Report of the West India Royal Commission, Vol. LI, Part XIII, Appendix A, (417); Hall 1964: 56-79.

19. Report of the West India Royal Commission, Vol. LI, Part XIII, (473), (475); Eisner 1961: 170-1, 205.

20. Ibid., Vol. L, Part III, (186), Vol. LI, Part XIII, (496), (498).

\section{REFERENCES}

Adamson, Alan H., 1972. Sugar without slaves: The political economy of British Guiana, 1838-1904. New Haven.

Barbour, IAN G., 1980. Technology, environment, and human values. New York.

BARETr, W ARD, 1965. Caribbean sugar-production standards in the seventeenth and eighteenth centuries. In John Parker (ed.), Merchants and Scholars. Minneapolis, pp. 147-70.

Barrow, Christine, 1983. Ownership and control of resources in Barbados: 1834 to the present. Social and Economic Studies 32,3: 85-92.

BEACHY, R.W., 1957. The British West Indies sugar industry in the late 19th century. Oxford.

BECKFORD, WILliAM, 1788. Remarks upon the situation of negroes in Jamaica. London.

- 1790. A descriptive account of the island of Jamaica (2 vols.). London.

Beckles, Hilary, 1984. Black rebellion in Barbados: The struggle against slavery, 1627-1838. Barbados. 
Belle, George, 1984. The Abortive Revolution of 1876 in Barbados. Journal of Caribbean History 18: 1-34.

BENNETT, J. HARRY, 1958. Bondsmen and bishops: Slavery and apprenticeship on the Codrington plantations of Barbados, 1710-1838. Berkeley and Los Angeles.

BhAtTY, I.Z., 1978. Technological change and employment: A study of plantations. Delhi.

Bigelow, JoHn, 1851. Jamaica in 1850: Or, the effects of sixteen years of freedom in a slave colony. New York.

CAMPBell, JoHN, 1774. A political survey of Britain (2 vols.). London.

Craton, Michael \& James Walvin, 1970. A Jamaican plantation: The history of Worthy Park 1670-1970. Toronto.

DAvY, JoHN M.D., F.R.S., 1854. The West Indies, before and since slave Emancipation. London.

DeERr, NoEL, 1949-50. The history of sugar (2 vols.). London.

Deerr, Noel \& Alexander Brooks, 1940-41. The early use of steam power in the cane sugar industry. The Newcomen Society for the Study of the History of the History of Engineering and Technology, Transactions, 21.

Dickson, WiLliam, 1789. Letters on slavery. London.

—_, 1969. Mitigation of slavery. Miami. (First published in 1814.)

EDWARDS, BRYAN, 1793. The history, civil and commercial, of the British colonies in the West Indies (2 vols.). Dublin.

EISNER, Gisela, 1961. Jamaica, 1830-1930: A study of economic growth. Manchester.

Fogel, RoBert William, f.p. Without consent or contract: The rise and fall of American slavery.

Galenson, David W., 1981. White servitude in colonial America: An economic analysis. Cambridge.

Green, William A., 1973. The planter class and British West Indian sugar production, before and after Emancipation. The Economic History Review 2nd Ser., 26, 3:446-63.

- 1976. British slave Emancipation: The sugar colonies and the Great Experiment 18301865. Oxford.

GoVEIA, ELSA V., 1965. Slave society in the British Leeward Islands at the end of the eighteenth century. New Haven.

Hall, Douglas, 1959. Free Jamaica, 1838-1865: An economic History. New Haven. 
1962. Slaves and slavery in the British West Indies. Social and Economic Studies 11, 4:305-18.

1964. The early banana trade from Jamaica, 1868-1905: A descriptive account. In Douglas Hall, Ideas and Illustrations in Economic History. New York, pp. 56-79.

Handler, Jerome S. \& Frederick W. Lange, 1978. Plantation slavery in Barbados: An archeological and historical investigation. Cambridge, Mass.

Higman, Barry W., 1984. Slave populations in the British Caribbean 1807-1834. Baltimore.

Hoyos, F.A., 1978. Barbados: A history from the Amerindians to Independence. London.

Levy, Claude, 1980. Emancipation, sugar, and federalism: Barbados and the West Indies, 1833-1876. Gainesville, Fla.

Lobdell, Richard A., 1972. Patterns of investment and sources of credit in the British West Indian sugar industry, 1838-97. The Journal of Caribbean History 4:31-53.

York.

Long, Edward, 1774. The History of Jamaica (3 vols.). London.

MacPherson, David, 1805. Annals of commerce (4 vols.). Edingburgh.

- 1963. Caribbean lands: A geography of the West Indies. London.

MARShall, W.K., 1968. Notes on peasant development in the West Indies since 1838. Social and Economic Studies 17,3: 252-63.

Martin, Samuel, 1802. An essay upon plantership in Three tracts on West indian agriculture. Jamaica.

Mintz, Sidney W., 1986. Sweetness and power: The place of sugar in Modern history. New York.

Olivier, Lord Sydney, 1971. Jamaica, the blessed island. New York.

PARes, Richard, 1960. Merchants and planters. (The Economic History Review Supplement 4). London.

Pringle, Hall, 1869. The fall of the sugar planters of Jamaica. London.

SCHOMBURGK, Robert H., 1848. The history of Barbados. London.

Sewell, William G., 1861. The ordeal of free labor in the British West Indies. New York.

Sheridan, R.B., 1960. Samuel Martin, innovating sugar planter of antigua, 1750-17761. Agricultural History 34,3: 126-39. 
1974. Sugar and slavery: An economic history of the British West Indies 1623-1775. Barbados.

- 1985. Doctors and slaves: A medical and demographic history of slavery in the British West Indies, 1680-1834. Cambridge.

SMIth, S. IvaN, 1975. Functional ecology of sugarcane in the American tropics. Caribbean Studies 15,3: 57-77.

Starkey, Otis P., 1939. The economic geography of Barbados. New York.

Trollope, Anthony, 1860. The West Indies and the Spanish main. London.

TURNER, MARY, 1982. Slaves and missionaries: The disintegration of Jamaican slave society, 1787-1834. Urbana, III.

Von Humboldt, Alexander, 1851. Journey to the Equinoctial regions. (Trans. Thomasina Ross). London.

Watson, Karl Stewart, 1975. The civilised island, Barbados, A Social History, 1750-1816. [Ph.D. dissertation, University of Florida.]

WATTS, DAvid, 1966. Man's influence on the vegetation of Barbados 1627 to 1800. Hull. - 1987 . The West Indies: Patterns of development, culture and environmental change since 1492. Cambridge.

Williams, ERIC, 1944. Capitalism and slavery. Chapel Hill, N.C.

RICHARD B. SHERIDAN

Department of Economics, Univ. of Kansas,

213 Summerfield, Lawrence, Kansas 66045-2113

U.S.A. 